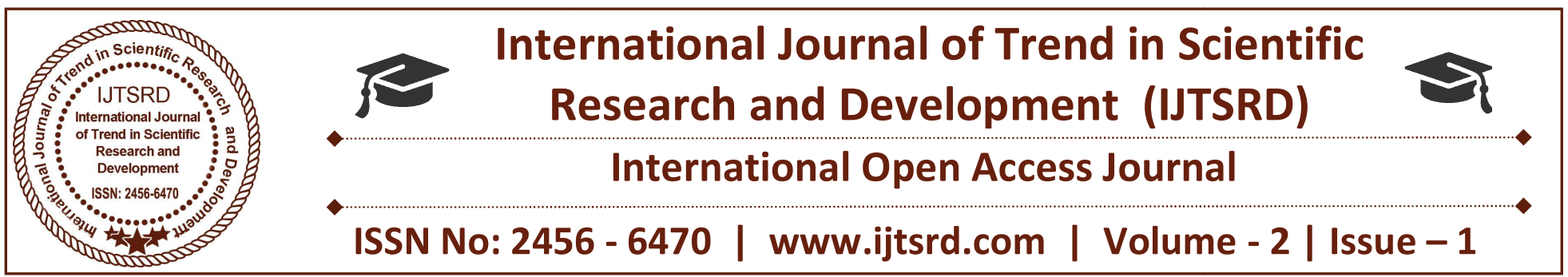

\title{
Effect of Tertiary Education Tax Fund (Tetfund) in Management of Nigerian Tertiary Institutions
}

\author{
Dr. A. O. Oraka \\ Department of Accountancy \\ Nnamdi Azikiwe University, \\ Awka, Anambra state, Nigeria
}

\author{
Dr. Cy Ogbodo \\ Department of Accountancy \\ Nnamdi Azikiwe University, \\ Awka, Anambra state, Nigeria
}

\author{
Raymond A. Ezejiofor \\ Department of Accountancy \\ Nnamdi Azikiwe University, \\ Awka, Anambra state, Nigeria
}

\section{ABSTRACT}

This study set out to determine the effect of Tertiary Education Tax Fund (TETFUND) on management in Nigerian tertiary education. Specifically, the study sought to determine whether ETF fund allocations to Nigerian Tertiary Institutions significantly affect the enrollment ratio to Nigerian Tertiary Institutions in Nigeria. The hypothesis was formulated in line with the objectives of the study. Survey and Time series research design were adopted. Data were obtained from National Bureau of Statistics by use of financial ratios and tested using regression analysis with aid of SPSS statistical package version 20.0. Based on the analysis, the study found that ETF fund allocations to Nigerian Tertiary Institutions have no correlation with the enrollment ratio of Nigerian Tertiary Institutions. Based on the findings, the study recommends that to the intervention agency to achieve meaningful on its constituents fund allocations should commensurate with enrolment ratio of tertiary institutions in Nigeria.

Keywords: Tertiary Education, TETFUND, management, University

\section{INTRODUCTION}

The Tertiary Education Trust Fund (TETFUND) was established by an Act of the National Assembly in June 2011. The Act replaced the Education Tax Fund Act Cap. E4 Laws of the Federation of Nigeria 2004 and Education Tax Fund (Amendment) Act No 17, 2003. Guidelines on assessing TETFUND (2015) asserted that Fund was set up to administer and disburse education tax collections to the Federal and
State tertiary educational institutions in Nigeria. The main source of income available to the Fund is the $2 \%$ education tax paid from the assessable profit of companies registered in Nigeria. The levies are collected by the Federal Inland Revenue Service (FIRS).

Education Tax Fund (ETF) however, was established by Education Tax Act No. 7 of 1993 and amended by Act No. 40 of (22nd Dec.) 1998. The Act imposes tax at the rate of $2 \%$ on the assessable profits of all incorporated bodies. The tax applies to all companies registered in Nigeria. These assessable profits of a company shall be ascertained in the manner specified in the companies Income Tax Act or the Petroleum Profits Tax Act as the case may be. What necessitated the promulgation of this Education Tax Act was the widely recognized decline in Educational standards and the deep rot in infrastructure and other facilities at all levels of the Nigerian educational system (Ugwuanyi, 2014).

The universities and other tertiary institutions were in a state of advanced decay with most of the teaching staff leaving the country in droves in search of greener pastures abroad. Apart from the impact of inadequate funding on the quality of the teaching and learning process in our institute of higher education, students support is now inadequate (Afolayan, 2015). The number of students from poor and disadvantaged background attending our higher institutions has become insignificant. The funding of higher education has been regressive over the years. It was therefore 
not surprising that the late Yar' Adua's administration had to be confronted by labour unions in the education sector with long lists of demands on what should be done to uplift the sector. The unions, one after the other had to embark on debilitating strike actions to press home their points and this resulted into the shutting of the universities for close to four months. Imhabekhai and Tonwe, (2001) highlighted that currently, universities education at present is underfunded, inadequate funding put the university management under stress and strains hence they are incapacitated in providing essential services. This has led to rampant crises in the system resulting in strikes by academic and non-academic staff, dearth of equipment and facilities, indiscipline among staff and students, upsurge in the activities of secret cults among others. Higher education relates to all forms of post-secondary education such as the Universities, Polytechnics, Colleges of Education, Monotechnics and Professional schools (Abdu 2003).

World Bank (2009) collaborate that equipment for teaching; research and learning are either lacking or very inadequate and in a bad shape to permit the universities the freedom to carry out the basic function (Agha, 2014).

Notwithstanding several interventions by TETFUND, there still exist poor educational facilities in Nigeria. The rate at which Nigerian universities are fast decaying is rapidly alarming. All the resources needed for education production process are in short supply such like; hostels, library space, lecture halls, laboratories, students' books and journals and office spaces are all seriously in a mess.

To this end, this study aim to appraise the Tertiary Education Tax Fund (TATFUND) in Nigerian Educational Development on the tertiary institutions, specifically to determine whether ETF fund allocations to Nigerian Tertiary Institutions have any correlation with the enrollment ratio to Nigerian Tertiary Institutions.

\subsection{Hypotheses}

$\mathrm{H}_{\mathrm{O}}$ : Education Tax Fund (ETF) allocations to Nigerian Tertiary Institutions do not have any correlation with the enrollment ratio of Nigerian Tertiary Institutions.

\subsection{CONCEPTUAL FRAMEWORK}

\subsection{Education Tax Fund}

The Education Tax Fund having been established by Education Tax Act No. 7 of 1993 and amended by the Act No. 40 of (22nd Dec) 1998 imposed the 2\% tax on all assessable profits of all companies registered in Nigeria. The collection of the tax fund however started in 1994. And the ascertainment was as specified in the companies Income Tax Act or the Petroleum Profits Act Tax as the case may be. This amendment brought about the establishment of Education Trust Fund as an intervention agency with project management to improve the quality of Education in Nigeria (Tech., 2011). The Federal Inland Revenue Service (FIRS) is empowered by the Act to assess and collect Education Tax. The fund administers the tax imposed by the Act, and disburses the amounts to educational institutions at federal, state and local government levels. It also monitors the projects executed with the funds allocated to beneficiaries.

The mandate of the Fund as provided in Section 5(1) (a) to (g) of the Act No. 7 is to administer and disburse the amount in the Fund to Federal, State, and Local Government Educational Institutions, including primary and secondary schools, for any other matter ancillary thereto, but specifically to the following: Work centres and prototype development; Staff development and conference attendance; Library systems at the different levels of education; Research equipment procurement and maintenance; Higher Education Book Development Fund;

By the year 2008, the Tertiary Education Trust Fund (TETFUND) came into being (Uzondu, 2012). This Tertiary Education Trust Fund (TETfund) was established as an intervention agency under the TETfund Act - Tertiary Education Trust Fund (Establishment, ETC) Act, 2011. This Act repeals the Education Tax Act Cap E4 Laws of Federation of Nigeria 2004 and Education Tax Fund Act No. 17, 2003 and established the Tertiary Education Trust Fund - charged with the responsibility for imposing, managing and disbursing the tax to public tertiary institutions in Nigeria (TETfund News Panaroma, 2013). To enable the TETfund achieve the above objectives, TETfund Act 2011 imposes a 2 percent Education Tax on the assessable profits of all registered companies in Nigeria. 
The vision of the TETfund is to be a world-class interventionist agency in Nigeria's Tertiary Education. Its mission is to provide focused and transformative intervention in public tertiary institutions in Nigeria through funding and effective project management. For the reason of efficient management and other reasons best known to the fund Board, they ruled out the inclusion of principal officers such as vice chancellors, rectors, provosts and their deputies, the directors of works, librarians etc as beneficiaries.

For the ETF operations, assessment and collection as at 1994 - 1999, and the distribution formula, the Act approves a secretariat for the fund, headed by an Executive Secretary and assisted by other management and support staff, under the direct supervision of the Board of Trustees. It also provides for zonal offices all over Nigeria to liaise with beneficiaries in project identification, data collection and communication with education institutions. The zonal offices also liaise with the Federal Inland Revenue Service in the respective zones to ensure that there is close monitoring of the assessment and collection of Education Tax.

The actual fund is managed by the Board of Trustees which oversees the allocation of tax collected in any one year among the various tertiary, secondary and primary institutions as provided for in the Act setting up the fund. The Board of Trustees has resolved to expend in any one year only what was collected in the previous year (Ugwuanyi,2014).

The Education Tax Fund Act assigned the responsibility of assessment and collection of the education tax from respective companies to the Federal Inland Revenue Service. The Board at its inauguration inherited the balance of the N10.3 billion being the amount collected as at the end of December 1998 less the amounts disbursed by the previous Board. Within the first five year period after the inception of the ETF, there was a gradual decline in the amounts of assessment and collection of taxes but with the inauguration of the Board on 28th September 1999 and a management put in place, the trend was reversed and prospects improved upon. The Education Fund (according to Section 5(2) of the Act No. 7 of 1993 ) is to be distributed as follows:-

- Higher Education - 50\% of the total tax collected in any one year.
- Primary Education - 40\% of the total tax collected in any one year.

- Secondary Education - $10 \%$ of the total tax collected in any one year.

The distribution for tertiary education is to be shared as between universities, polytechnics and Colleges of Education in the ratio of $2: 1: 1$ OR $25 \%: 12.5 \%: 12.5 \%$. The 1998 amendment changed the disbursement to 50\% (Tertiary education); 30\% (Primary education) and $20 \%$ (Secondary education).

There are procedures, according to one of the publications of the ETF (of 26th April, 2001), that must be followed and the project cycle adopted by ETF shall be Jan-Dec i.e. 12 months in any particular year. For identification and prioritization, the beneficiaries are to identify very critical areas (in their various establishments) that need immediate interventions, which in most cases are many and depend on the age of the institutions). The projects would need to be prioritized (because of competing needs) by the beneficiaries in conjunction with the Departments of Operations of the ETF based on the available fund but in the specific areas of ETF mandate, such that the projects would have immediate and lasting impact on the program of the institutions (Ugwuanyi,2014).

Based on prioritization, the beneficiaries would submit their proposals to the Department of Operations of the ETF for approval on behalf of the Board. The approval of such projects shall be set against predetermined cost limit, and on no account should projects already approved with cost limits be altered without the consent of the fund for timeliness, effectiveness, and to ensure easy supervision of the projects. The Department of Operations of the ETF will vet the submission from the beneficiaries, using the prevailing market rates and setting the cost limit for each project. And a letter of approval of projects setting the cost limits shall be released to the beneficiary together with the first tranche of the allocation to be determined by the Board from time to time.

Approval is followed by tender and award of the contract. When project is awarded, the implementation involves the actual execution phase of the projects using the approved fund; disbursing the funds to the institutions in three (of $40 \%, 35 \%$ and $25 \%$ ) or two $(75 \%$ and $25 \%$ ) installments depending 
on the types of projects being embarked upon. At the end, evaluation phase will analyze the impact of the projects - highlighting the gains or otherwise of the institution's during and/or after the implementation. The Department of Operations would document the lesson learnt from the experience on the projects to be used to improve the performance of future projects of the Education Tax Fund. The final accounts of the projects must be clearly presented by the beneficiary where the as-built-in costs would be reflected (Ugwuanyi,2014).

Emphasis was placed on science and technology, due to the expensive nature of training within the country. The funding was increased to N60 million in 2009 and then to N80 million. In all, each university, federal and states on equality basis from 2008 to 2011 have received N240 million for staff training alone. "Virtually, all the capital projects seen in many of the state institutions certainly not all, are actually ETF funded. And there is no institution in this country, public tertiary institution, where there is no ETF projects (Rufai, 2012). The agency has been attending to a growing number of institutions, as seen in geometric rise in the numbers of the institutions: from 37 universities in 1994, to the present funding of 73 universities, with new additions streaming in, 43 polytechnics in 1999 to 50 present polytechnics; and 60 colleges of education in early 2000 to 63 now, with Gombe and Bayelsa about to establish their colleges of education, hence by next year, there will be 65 colleges of education. Several other ancillary funding that the agency has undertaken include the Graduate Teachers Training Scheme, the Academic Publishing Scheme, The National Research Fund, the Almajiri Education Programme, the Textbooks Distribution Projects for primary and junior secondary schools which was recently flagged off by the President.

The provision of needed infrastructure for learning at the tertiary level represents one major milestone in the achievement recorded by TETfund. The appointment of the boss of the agency to chair the NEEDS assessment committee visits to universities, no doubt contributed immensely to the resuscitation of dilapidating infrastructures in our higher institutions of learning. Today, TETfund had drawn the attention of government to the yearning needs of our universities, and the global ranking of our universities have as well improved (Rufai, 2012). Introduced by the TETfund (in 2009) with the support of the government is what is also called "The Special High Impact Project," where certain amount, N3 billion is given to a university and N1 billion to polytechnics and colleges of education on the equality of each of the six geopolitical zones to have one university and a polytechnic, or one university and a college of education.

\subsection{Funding of Tertiary Education}

Tertiary education can be defined as the level of education acquired after secondary education in higher institutions of learning such as Universities, Polytechnics, Colleges of education and other institutions of higher learning offering correspondence courses, diplomas and certificates. Ahmed (2011) opined that the challenges confronting tertiary institutions in Nigeria include financing and funding, the growth of private tertiary institutions, management challenges and so on but the challenge dealing the worst deathblow is that of underfunding of tertiary institutions. Nwangwu (2005) stated that the foundation of education is frail when education is not well funded and the products of such foundation are weak intellectuals. When there were just few tertiary institutions, Government saddle the burden of funding the institutions solely but from the mid-1980's there was a massive increase in the number of tertiary institutions and in students' enrolment in Nigeria. This increase has gotten to the point where Government openly acknowledged that it can no longer saddle the responsibility of funding institutions alone.

\subsection{Management of University Education in Nigeria}

Management of university education can be looked at from two dimensions; the external and the internal levels. At the external level, this is the control by the federal government through the National Universities Commission (NUC), a body charged with the coordination of university management in the country. According to Ibukun (1997), the main objectives of the NUC are to ensure the orderly development of university education in Nigeria, to maintain its high standard and to ensure its adequate funding. Okojie (2007) posited that the NUC activities in improving quality of university education in the country include:

i. Accreditation of courses.

ii. Approval of courses and programmes.

iii. Maintenance of minimum academic standards.

iv. Monitoring of universities. 
International Journal of Trend in Scientific Research and Development (IJTSRD) ISSN: 2456-6470

v. Giving guidelines for setting up of universities.

vi. Monitoring of private universities.

vii. Prevention of the establishment of illegal campus.

viii. Implementing appropriate sanctions.

On the other hand, the internal management of each university is represented by a simple organogram. The first is the Visitor who is usually the Head of State or the Head of Government that established it (The President in case of federal universities and the Governors in case of state universities). He usually comes to grace the convocation ceremonies where he uses the occasion to address the academic communities on matters of the moment (Adegbite, 2007). The second is the Chancellor, who is the titular head of the university, who by law, in relation to the university, takes precedence before all other members of the university and when he is present, presides at all meetings of the convocation held for con ferrying degrees.

Besides, at the ape of the management structure within each university is the Governing Council, headed by the Chairman (Pro-Chancellor) which is charged with the administrative functions in the areas of goal setting policy formulation, staff development, general discipline, budget approval and liaison activities with the government.

In addition to this, there is the Senate, headed by the Vice-Chancellor and the Registrar as the Secretary. The Senate regulates the academic activities of the university following the general guidelines provided by the NUC. According to Mgbekem (2004), the universities in Nigeria are run through committee systems which are either responsible to the Council or the Senate, among these committees are:

i. Finance and General Purpose committee.

ii. Development committee.

iii. Appointments and Promotion committee.

iv. Admissions committee.

v. Academic Planning committee.

vi. Committee of Deans.

vii. Research Grants committee.

viii. Ceremonies committee, among others.

\subsection{Effects of Inadequate Funding on Performance of Tertiary Institutions}

Agha (2014) noted that the problem of underfunding which is a major challenge confronting the Nigerian
University system has had adverse effects on the performance of the universities. Fasihul (2003) notes that the by-effects of dwindling finances in the Nigeria University system are explicated in many adaptive mechanisms such as:

(i) Curtailing of laboratory/practical classes.

(ii) Limited number of field trips.

(iii) Reduction in the rate of attendance of academic conferences.

(iv) Reduction in the purchase of library books, chemicals and basic laboratory equipment.

(v) Embargo on new employment

(vi) Embargo on study fellowships and

(vii) Reduction in research grants away others.

Odebiyi and Aina (2007) maintain that the inadequate funding of universities and other tertiary institution has had adverse effects on teaching and research and the universities have been forced to embark on income generating projects in order to source for funds. This tends to be responsible for series of industrial actions embarked upon by the Academic Staff Union of Universalities (ASUU). Poor funding also impacted on staff recruitment and staff development policy. Bamiro and Adedeji (2010) noted that the Nigerian government spends just 0.1 percent on research, while federal universities spend only 1.3 percent of their budgets on research. This has implications for development, because research constitutes a veritable catalyst for the economic advancement of nations and adequate funding is the propeller for research.

The effects of inadequate funding are evident in the fact that the physical facilities in respective universities are in a state of disrepair, several capital and research projects have been abandoned, laboratories and libraries are ill equipped, academic staff do not attend conferences regularly and there is a drastic reduction in the award of research grants and fellowship (Agha, 2014). Although the National policy on education acknowledges the fact that adequate funding is a criterion for the success of any educational programme, Adeniyi (2008) however noted that there is a general reduction in efficiency and productivity of universities because of dearth of funds.

\subsection{Resource-based theory}

The resources based theory of the firm blends concepts from organizational economics and strategic management (Barney, 1991). A fundamental assumption of this view is that organizations can be 
successful if they gain and maintain competitive advantage (Porter, 1985). Competitive advantage is gained by implementing a value-creating strategy that competitors cannot, easily copy and sustain (Barney, 1991) and for which there are no ready substitutes. For competitive advantage to be gained, two conditions are needed. First, the resources available to competing firm must be variable among competitors, and second, these resources must be immobile (i.e. not easily obtained). Three types of resources associated with organizations are:

\section{i. Physical (plant; technology and equipment;} geographical location)

ii. Human (employees' experience and knowledge); and Organizational (structure; systems for planning, monitoring, and controlling activities; social relations within the organization and between the organization and external constituencies) The Resource-Based theory is adopted for this study as a medium of sustaining financing of Nigerian tertiary institutions. This is because in Nigerian tertiary institutions are being under-funded in terms of budgetary allocation on operational costs and revenue generation.

\subsection{Empirical Review}

There are number of research on the Education Tax Fund and their management in Nigerian Tertiary institutions.

Agha (2014) examined funding university Education in Nigeria and its implications on the performance of these institutions. The African political economy model was used in explaining the financial state of Nigerian Universities. The findings revealed that although the Federal Government provides about 90 percent funds, it has not been able to successfully finance the system due to economic, social and political depression. This is evident in poor quality of teaching and research, poor conditions of work and insufficient attention to staff development. The consequence is that goals of university education in Nigeria are yet to be achieved.

Ekundayo and Ajayi (2009) examined the myriads of problems militating against the effective management of the Nigeria university education system. According to their study, these include: financial crisis, poor infrastructure, and brain-drain, erosion of university autonomy, graduate unemployment, volatile and militant students' unionism, secret cults, examination malpractices and sexual harassment.
Ugwoke (2013) on Education tax law and administration in Nigeria examines the administration of the ETD of 1993 as amended by the Act No 40 of 1988. It concludes that with improved transparency and accountability, rigorous training and retraining of the staff of the fund in tax audit and monitoring of project implementation, encouragement of the beneficiaries of the fund to shun their current lackadaisical attitude to the accessing and utilization of the Education Trust Fund money, the Education Tax Act will survive the present onslaught by the organized private sector who is recently very vocal about and against multiple taxation in the economy.

Adeyemi (2011) examined the financing of education in Nigeria. A review of the finances on education since the advent of formal education in the country was made. The study shown the total revenue accruing to the Federal Government and the amount of money allocated to the education at various periods indicating deficits in the funding of the system. The findings indicated that the funding of education has not been up to $17 \%$ in any given year despite the UNESCO minimum standard of $26 \%$ of national budget. The writer therefore made suggestions on how to effectively fund education in the country and recommended other sources of funding education for future development.

Ugwuanyi (2014) undertakes an eleven-year period study of the activities of Education Tax Fund (ETF) upon Nigerian tertiary institutions with the target of revealing how Education Tax Fund has helped in enhancing the educational development of Nigerian Tertiary Institutions. Various analytical tools were employed in appraising data generated from the publications of the operations department of the Education Tax Fund and some other Federal Government publications. The research found out that ETF has made significant positive impact towards improving the educational sector in Nigeria by construction of various intervention projects and improving the teaching and learning conditions of both students and lecturers., and that each tertiary institution has its own criteria (subject to TETfund directives) for determining which lecturer becomes a beneficiary. Conclusively, the researcher is of the opinion that the ETF has the potential of alleviating the chronic under-funding of the educational sector and that in future, if properly utilized the fund will continue in no small measure towards revitalizing the educational system in Nigeria. 
Afolayan (2015) examine the trend in funding of higher education in Nigeria and the attendant effect between 2009 and 2013. The paper observed some gaps in the funding and in the expenditure of available funds. The study analyzed the response to the report of the needs assessment of Nigerian Universities conducted in 2012, the federal government earmarked N1.3trtillion for special intervention in the Nigerian public universities over the next Six (6)years, of which N200billion out of the amount has been released. The paper was concluded by making appropriate recommendations to addressing the identified challenges.

From all the research conducted on tertiary education fund, there still exist poor educational facilities in Nigeria. The rate at which Nigerian universities are fast decaying is rapidly alarming. All the resources needed for education production process are in short supply such like; hostels, library space, lecture halls, laboratories, students' books and journals and office spaces are all seriously in a mess.

\subsection{METHODOLOGY}

\subsection{Research Design}

Ex-post facto method was adopted in this study because the study involves collection of data to access the contributions of ETF in Nigerian Tertiary institutions.

\subsection{Method of Data Analysis}

Data collected for the study was extracted from National Bureau of Statistics. The hypothesis formulated was tested using regression analysis with aid of Statistical Package for Social Sciences (SPSS) version 20.0 software package.

\subsubsection{Model Specification}

To establish the effect of STDENT and this model was developed:

STDENT $_{\mathrm{t}}=\beta 0+\beta 1 \mathrm{UNITFt}+\beta 2$ COGEDUt $+\beta 3$ PLYTECHt $\varepsilon 1 \ldots \ldots \ldots \ldots . .1$

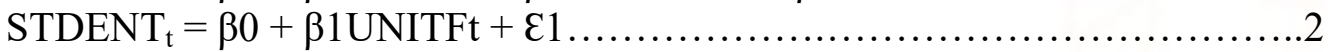

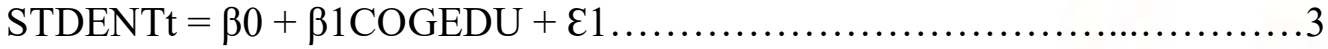

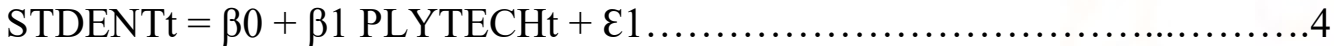

Using SPSS, 5\% is considered a normal significance level. The accept reject criterion was based on the computed R-value.

\subsection{DATA PRESENTATION AND INTERPRETATION}

\subsection{Data Presentation}

Table 1: ETF Fund Allocations to Nigerian Tertiary Institutions and Student enrollment (1999 - 2014)

\begin{tabular}{|c|c|c|c|c|c|}
\hline Years & University (N) & $\begin{array}{l}\text { Colleges of } \\
\text { Education (N) }\end{array}$ & Polytechnics (N) & Total(N) & $\begin{array}{l}\text { Students } \\
\text { Enrollment }\end{array}$ \\
\hline 1999 & $2,124,999,960$. & $1,099,137,930$ & $1,087,209,288$ & $4,311,347,178$ & 172,259 \\
\hline 2000 & $1,050,000,000$ & $520,000,000$ & $450,000,000$ & $2,020,000,000$ & 191,040 \\
\hline 2001 & $1,794,128,000$ & $1,108,048,500$ & $967,500,000$ & $3,869,676,500$ & 217277 \\
\hline 2002 & $3,243,500,000$ & $1,742,625,000$ & $1,642,500,000$ & $6,628,625,000$ & 287368 \\
\hline 2003 & $1,440,500,000$ & $678,625,000$ & $634,500,000.00$ & $2,753,625,000$ & 304849 \\
\hline 2004 & $1,515,750,000$ & $744,625,000$ & $722,750,000$ & $2,983,125,000$ & 461494 \\
\hline 2005 & $2,025,000,000$ & $1,249,000,000$ & $1,657,500,000$ & $4,931,500,000$ & 428467 \\
\hline 2006 & $2,475,000,000$ & $1,240,000,000$ & $1,302,000,000$ & $5,017,000,000$ & 118056 \\
\hline 2007 & $3,659,000,000$ & $1,579,900,000$ & $1,430,000,000$ & $6,668,900,000$ & 399470 \\
\hline 2008 & $7,112,000,000$ & $3,824,160,000$ & $3,611,520,000$ & $14,547,680,000$ & 444090 \\
\hline 2009 & $6,858,000,000$ & $3,760,920,000$ & $3,472,320,000$ & $14,091,240,000$ & 490809 \\
\hline 2010 & $16,672,700,000$ & $9,587,370,000$ & $9,055,000,000$ & $35,315,070,000$ & 1438894 \\
\hline 2011 & $13,044,770,000$ & $6,260,740,000$ & $7,547,430,000$ & $26,852,940,000$ & 2183918 \\
\hline 2012 & $285,800,000,000$ & $32,100,000,000$ & $33,900,000,000$ & $125,800,000,000$ & 2297257 \\
\hline 2013 & $64,600,000,000$ & $39,000,000,000$ & $44,300,000,000$ & $147,900,000,000$ & 2994734 \\
\hline 2014 & $91,200,000,000$ & $58,100,000,000$ & $66,100,000,000$ & $215,400,000,000$ & 3520980 \\
\hline
\end{tabular}


Source: National Bureau of Statistics (2014)

There are 36 federal universities, 37 state universities, and 45 private universities accredited by the National Universities Commission (NUC) in Nigeria. The above table shows the level of individual institutions fund allocations to total allocations for all the tertiary institutions under review and depicts that an average of $50 \%$ of the total yearly allocations goes to the University system and the other $50 \%$ shared between Colleges of Education and Polytechnics.

\subsection{Test of Hypotheses}

$\mathrm{H}_{\mathrm{O}}$ : ETF fund allocations to Nigerian Tertiary Institutions do not significantly affect the enrollment ratio to Nigerian Tertiary Institutions.

$\mathrm{H}_{\mathrm{I}}$ : ETF fund allocations to Nigerian Tertiary Institutions significantly affect the enrollment ratio to Nigerian Tertiary Institutions.

\begin{tabular}{|c|c|c|c|c|c|}
\hline \multicolumn{6}{|c|}{ Model Summary ${ }^{b}$} \\
\hline Model & $\mathrm{R}$ & R Square & $\begin{array}{l}\text { Adjusted } \quad \mathrm{R} \\
\text { Square }\end{array}$ & $\begin{array}{l}\text { Std. Error of the } \\
\text { Estimate }\end{array}$ & Durbin-Watson \\
\hline 1 & $.922^{\mathrm{a}}$ & .850 & .812 & 486292.82064 & 1.291 \\
\hline $\begin{array}{l}\text { a. } \\
\text { POLYT }\end{array}$ & \multicolumn{2}{|c|}{$\begin{array}{l}\text { Predictors: (Constant), } \\
\text { TECHNICTETFUND }\end{array}$} & \multicolumn{2}{|c|}{ COLLEGETETFUND, } & RSITYTETFUND, \\
\hline b. Dep & lent $\mathrm{Va}$ & STUDENT & ROLL & & \\
\hline
\end{tabular}

Table above table shows the Model summary and overall fit statistics. We find that the adjusted $\mathrm{R}^{2}$ of the model is .812 with the $\mathrm{R}^{2}=.850$ that means that linear regression explains $85 \%$ of the variance in the data.

\begin{tabular}{|c|c|c|c|c|c|c|}
\hline \multicolumn{7}{|c|}{ ANOVA $^{\mathbf{a}}$} \\
\hline \multicolumn{2}{|c|}{ Model } & Sum of Squares & df & Mean Square & $\mathrm{F}$ & Sig. \\
\hline \multirow[t]{3}{*}{1} & Regression & $\begin{array}{l}1604026820933 \\
5.473\end{array}$ & 3 & $\begin{array}{l}5346756069778 . \\
491\end{array}$ & 22.610 & $.000^{\mathrm{b}}$ \\
\hline & Residual & $\begin{array}{l}2837768488866 . \\
274\end{array}$ & 12 & $\begin{array}{l}236480707405.5 \\
23\end{array}$ & & \\
\hline & Total & $\begin{array}{l}1887803669820 \\
1.746\end{array}$ & 15 & & & \\
\hline \multicolumn{7}{|c|}{ a. Dependent Variable: STUDENTSENROLL } \\
\hline \multicolumn{7}{|c|}{$\begin{array}{l}\text { b. Predictors: (Constant), COLLEGETETFUND, UNIVERSITYTETFUND, } \\
\text { POLYTECHNICTETFUND }\end{array}$} \\
\hline
\end{tabular}

\begin{tabular}{|c|c|c|c|c|c|c|}
\hline \multicolumn{7}{|c|}{ Coefficients $^{\mathrm{a}}$} \\
\hline \multirow{2}{*}{\multicolumn{2}{|c|}{ Model }} & \multicolumn{2}{|c|}{$\begin{array}{l}\text { Unstandardized } \\
\text { Coefficients }\end{array}$} & \multirow{2}{*}{$\begin{array}{l}\text { Standardized } \\
\text { Coefficients } \\
\text { Beta }\end{array}$} & \multirow[t]{2}{*}{$\mathrm{t}$} & \multirow[t]{2}{*}{ Sig. } \\
\hline & & $\mathrm{B}$ & Std. Error & & & \\
\hline \multirow[t]{4}{*}{1} & (Constant) & 409471.240 & 162980.975 & & 2.512 & .027 \\
\hline & UNIVERSITYTETFUND & $7.563 \mathrm{E}-007$ & .000 & .049 & .222 & .828 \\
\hline & POLYTECHNICTETFUND & $7.054 \mathrm{E}-005$ & .000 & 1.224 & .287 & .779 \\
\hline & COLLEGETETFUND & $-2.171 \mathrm{E}-005$ & .000 & -.333 & -.076 & .941 \\
\hline
\end{tabular}

The ANOVA table above has $\mathrm{F}=.22 .610$ and 15 degrees of freedom, the test is highly significant, thus we can assume that there is linear relationship between the variables in our model. 
The above coefficients table shows the regression coefficients, the intercept and the significance of all coefficients and the intercept in the model showing that there is a significant relationship between corruption and domestic investment in Nigeria. therefore, we reject null hypothesis and accept alternative hypothesis which state that ETF fund allocations to Nigerian Tertiary Institutions significantly affect the enrollment ratio to Nigerian Tertiary Institutions.

\subsection{DISCUSSION OF FINDINGS}

From the hypotheses tested, it was observed that the Education Tax Fund (ETF) has positively impacted in Nigerian Educational Development with particular focus on Tertiary institutions. According to the second hypothesis, ETF fund allocations to Nigerian Tertiary Institutions have correlation with the enrollment ratio to Nigerian Tertiary Institutions. Table 1 show the level of individual institutions fund allocations to total allocations for all the tertiary institutions under review and depicts that an average of $50 \%$ of the total yearly allocations goes to the University system and the other $50 \%$ shared between Colleges of Education and Polytechnics. Hypothesis three stated that the increased debt burdens coupled with the high population of students in all educational institutions as well as the rising cost of administering the states are among the reasons bewildering the financing of education in the country. There is lack of Loans could also be sought for personnel training for capacity building and technical know-how.

This finding is in line with Ugwuanyi (2014) whose study revealing that Education Tax Fund has help in enhancing the educational development of Nigerian Tertiary Institutions. Also on the other hand according to hypothesis three, Adeyemi (2011) who indicated that funding of education has not been up to $17 \%$ in any given year despite the UNESCO minimum standard of $26 \%$ of national budget.

\subsection{CONCLUSION AND RECOMMENDATIONS}

\section{Conclusion}

The findings of this research therefore revealed that ETF has been able to make significant positive impact towards improving the educational development in
Nigerian tertiary institutions. Hence, this study agrees that ETF has impacted positively in Nigerian Educational Development with particular focus on Tertiary institutions. Though ETF fund allocations to Nigerian Tertiary Institutions have no correlation with the enrollment ratio to Nigerian Tertiary Institutions but the major challenges facing ETF has effected on efficient administration and management of the Education Tax Fund in Nigerian Tertiary institutions in the sense that infrastructure base that will enhance quality in our nation's universities these days, the Inadequate monitoring of those trusted with TEF to ensure proper channeling of these fund appropriately.

The Education Tax Fund, though sourced at a rate of $2 \%$ on the assessable profits of all registered companies in Nigeria, it seems to be a mustard seed which grows into a giant tree only to fruit in thousands. Based on the findings of the study, the study deems it fit to make some necessary suggestions;

1. There is need for a transformation within the university system, so that the challenges of chronic under funding can be addressed.

2. The intervention agency to achieve meaningful on its constituents fund allocations should commensurate with enrolment ratio of tertiary institutions in Nigeria.

\section{REFERENCES}

1) Ajayi I.,A, \& Ayodele, J.B. (2004). Fundamentals of educational management, Ado-Ekiti: Green Line Publishers.

2) Aigbokan, B.P, \& Imahe, O.J. (2004). Education expenditure and human capital development in Nigeria: And Correlation so far? Lagos, Canon Publishers Nig. Ltd.

3) Akindutire, I.O. (2004). Administration of higher education. Lagos: Sunray Press.

4) Ajetomobi, J.O, \& Anyanwele, A.B (2004). Education allocation, unemployment and economic growth in Nigeria. Port Harcourt, Belk Publishers.

5) Alkasun, A. (1986). The Nigerian Economic Crisis: Causes and Solutions. Owerri, Canum Publishers Nig. Ltd.

6) Attahiru, M.J. (2006). Education Democracy and National Integration in Nigeria in the 21st Century. Lagos, Longman Nig. Plc. 
7) Ayodele O.O. (2006). Tax Policy Reforms in Nigeria, Lagos, Longman Nigeria Plc.

8) Babalola, J. (2001). University Funding Responses and Performances under a Declining Economy in Nigeria. Staff Research and Seminar Series: Educational Planning and Policy Unit, Department of Educational Management, University of Ibadan, Nigeria.

9) Bangura Y (1994). Intellectuals, economic reform and social change: constraints and opportunities in the formation of a Nigerian technology. Dev. Change 25(2):261-305.

10) Balami, D. (2002). Finance of Education in Nigeria. Paper presented at the forum on Cost and finance of Education in Nigeria, Abuja.

11) Bruce F, Akhilu H (1992). Adjusting Educational Policies Concerning Resources while Raising school Quality. Lagos, Heinemann Books Ltd.

12) Daily Independent (2009). Nigeria: Unutilized N22.6 Billion Education Trust Fund's Money", Daily Independent. 6th April.

13) Durosaro, D.O (1995). Controversial Issues in Nigerian Educational System. Lagos, Longman Nigeria Plc.

14) Education Trust Fund Publications (2000). Education Tax Fund at a Glance," Abuja

15) Education Trust Fund (2006). The House of Journal of Education Tax Fund, 2(3).

16) Ekundayo, H. T. \& Ajayi, I. A. (2009). Towards effective management of university education in Nigeria. International NGO Journal Vol. 4 (8), pp. 342-347, August, 2009. Available online at http:// www.academicjournals.org/INGOJ

17) Eze, S. (2011). Nigeria: ETF Cannot Solve All Education Problems - Mahmood (1). January, 20. Education, Nigeria, West Africa.

18) Education Trust Fund (1993). Establishment of Education Tax Fund: A Supplement to Nigerian Official Gazette No. 7 of 1993, Lagos, Government Printer.

19) Education Trust Fund (2006). The House of Journal of Education Tax Fund, 2(3).

20) Federal Ministry of Education (2002). Historical Background on the development of Education in Nigeria. Abuja, Published with support from UNESCO/Japan Trust Fund Project 532. NIR1010.
21) Federal Ministry of Education (2003). Education Sector Status Report. Abuja, Published with support from UNESCO/Japan Trust Fund Project 552. NIR 1010.

22) Federal Ministry of Education (2003). PreDiagnostic Bibliography Collation on Studies Proposed for the Nigerian FME Abuja, Published with support from UNESCO/ Japan Trust Fund Project 552. NIR1010.

23) Famade Oladiran Afolayan (2015). Funding higher education in Nigeria, IOSR Journal of Research \& Method in Education (IOSR-JRME) e-ISSN: 2320-7388,p-ISSN: 2320-737X 5(1)), PP 63-68 www.iosrjournals.org DOI: 10.9790/7388-05116368 www.iosrjournals.org

24) Harbison, F.H. \& Myers, G.A. (1964). Education, Manpower and Economic Growth: Strategies for Human Resources Development. New York. McGraw Hill. http:education.stateuniversity.com/pages/2015/go vernment- Education-changingRole-html.

25) Ibukun, W.O. (1997). Educational management: theory and practice. Ado-Ekiti: Green Line Publishers.

26) Igborgbor, G.C. (2005). Refocusing Education in Nigeria: A book of Readings. Benin, Alphabet Nigerian Publishers Ltd.

27) Jaiyeoba AO (2006). School administration and supervision. In J. B. Babalola, A. O. Ayeni, S. O. Adedeji, A. A. Suleiman and M. O. Arikewuyo (eds). Educational management: thoughts and practice.Ibadan: Codat Publications.

28) Lewis, W.A. (1967). Education and Economic Development in: Social and Economic Studies. $\mathrm{X},(2)$.

29) Mgbekem, S.J.A. (2004). Management of university education in Nigeria .Calabar: UNICAL Press.

30) Mohammed, S.A. \& Adamu, S.H. (1999). Education Tax Fund: Matters Arising (1)." The Punch Tuesday April 6.

31) NUC (2004). Report on the performance of the federal university system in 2002. Presented at the special meeting convened by the Honourable Minister of Education on Thursday, December 12.

32) Odukunle, K.S. (2001). Funding of university education under democratic rule in Nigeria: 
problems and prospects. Proceedings of the $12^{\text {th }}$ general assembly of SSAN.

33) Ogunbameru, O.A. (2004). Personality dimension to cultism in Nigerian tertiary institutions: a sociological perspective. JHE. 16(2): 91-98.

34) Ojedele, P. \& Ilusanya, G. (2006). Planning and policy of higher education in Nigeria. In J. B. Babalola, A. O. Ayeni, S. O. Adedeji, A. A. Suleiman and M. O. Arikewuyo (eds). Educational management: thoughts and practice. Ibadan: Codat Publications.

35) Olakunri, O. (2006). Education Tax Fund Allocation and Disbursements". Education in Nigeria. The House J. Education Trust Fund Vol.2, No.3, 2nd Quarter Edition.

36) Rufai, R.A. (2012). Federal Government Allocates N25 Billion to Tertiary Institutions, Abuja. The National Universities Commission.

37) Saint W, Hartnet TA, Strassner E (2003). Higher education in Nigeria: a status report. Higher education policy. $16: 259-281$.

38) Shu'ara, D. (2010). Higher Education Statistics Nigeria Experience in Data Collection. Director, Tertiary Education, Federal Ministry of Education, Abuja; a Paper Presented at the UNESCO Institute of Statistics Workshop on Education Statistics in Anglophone Countries, Windhoek, 17th - 21st October, 2010.

39) Smah OS (2007). Violent campus cultism: implication for university management. In J. B. Babalola and B. O. Emunemu (eds). Issues in higher education: research evidence from subsahara Africa. Lagos: Bolabay Publications.

40) Soludo, C.S. (2006). Can Nigeria be the China of Africa?", A Lecture Delivered at the Founders' Day of the University of Benin, Benin City, Nigeria on November 23.

41) Tech, N. Thick (2011-2013). Education Trust Fund." Resourcedat Powered Exclusively.

42) TETfund News Panaroma (2013). Tertiary Education Trust Fund." February Edition, www.tetfund.gov.ng.

43) Ugwoke R.O. (2013).Education tax law and administration in Nigeria .Wudpecker Journal of Public Administration 2013 Wudpecker Journals 1(2), pp. 028 - 036, November 2013.
44) Ugwuanyi, G. O. (2014).Taxation and Tertiary Education Enhancement in Nigeria: An Evaluation of the Education Tax Fund (ETF) Between 1999-2010 Journal of Economics and Sustainable Development. 5(6), 2014 www.iiste.org

45)Ukeje, B.O. (1986). Education for Social Reconstruction. Owerri, Mcmillian.

46) Uzondu, J. (2012). Funding, Not Problem of Education in Nigeria. Prof Yakubu. Monday April 23, Leadership Forum Nigerian New World.

47) Williams, L.H. (2000). A short survey of education in Nigeria. Lagos, Longman Nigeria Plc. 